УДК 616-089.168.1-06-037:616.381-07-089

\title{
A.F. Grynchuk,
}

\section{F.V. Grynchuk,}

\section{I.Iu. Polianskiy}

HSEE of Ukraine "Bukovinian State Medical University", Chernivtsi

Key words: acute peritonitis, postoperative complications, prognosis.

\section{A SCALE FOR PREDICTING POSTOPERATIVE SEPTIC COMPLICATIONS AT ACUTE PERITONITIS}

\footnotetext{
Introduction

An important component of the treatment of acute peritonitis is the ability to prognose adequately the possibility of postoperative complications, which allows to use appropriate preventive measures $[2,4$, 7]. For the case, mentioned above, numerous methods, based on the account of various parameters $[1,7,8,9]$, have been developed. But none of them is fully accepted, due to several reasons, including a large number of parameters that determine the complexity of use, low informative methods based on a small number of criteria, etc. As a result, APACHE, SAPS, SOFA and other scales [8, 9] which allow to estimate the severity of the patients and possibility of death are suggested for predicting the effects of treatment. Mannheim peritonitis index (MPI) [5] is acknowledged in many countries, but its only function is determination of the peritonitis severity. It is clear, that with the increasing of peritonitis severity and the patients condition, the probability of postoperative complications increases, but the above mentioned methods do not allow to differentiate the risk of separate postoperative complications. We should notice that the vast majority of prognostic scales allow to determine postoperative complications (C) A.F. Grynchuk, F.V. Grynchuk, I.Iu. Polianskiy, 2016
}

risk only after the operation. This reasons the limit of the applicability of preventive measures during the preoperative preparation. So, the question of informative prognostic scale development is important.

\section{The aim of the study}

To develop an informative scale for postoperative complications prediction.

\section{Material and methods}

The retrospective analysis of treatment consequences the of 169 patients with acute surgical pathology, complicated by various forms of peritonitis, aged 17 to 84 years was conducted. Male-98, female - 71 were chosen. Among them there were 51 cases of acute appendicitis, 26 - acute intestinal obstruction (non malignant), 23 - gastroduodenal ulcer perforations, 16 - strangulated hernia, 13 - acute cholecystitis and colon cancer, complicated by intestinal obstruction, 4 - obstetrical and gynecological pathology, 3 - perforation and injuries of the small intestine, 2 acute pancreatitis and postoperative peritonitis and 2 cases of other pathology. 45 patients were diagnosed with local peritonitis, 53-with diffuse, 57 with poured, 13 with total. 79 patients had postoperative comp- 
lications, including 24 cases of inflammation and wound suppuration, 5 - eventerations, 14 - intraabdominal abscesses and infiltrates, 18 - of intestinal suture failure, 18 - continious peritonitis. Death occurred in 39 patients. 123 patients were diagnosed with comorbidities.

The clinical and anthropometric data, laboratory methods, MPI parameters, comorbidity class (CC) [7], age were analysed. The factor impact was studied, using the variance analysis. The clinical manifestations of peritonitis before the operations were evaluated in points: local peritonitis - 2 diffuse - 4 , diffuse or general -6 points. To create the possibility of mathematical presence and severity of complications processing was evaluated as follows: 0 - no POC, 1 - inflammatory wound complications 2 wound suppuration and eventration, 3 - bordered intra-abdominal complications, 4 - suture leakage and diffuse peritonitis, 5 - total peritonitis with systemic complications, that lead to death. Numerical characteristics of surgical diseases were conferred according to the univariate variance analysis results.

\section{Discussion of the study}

A scale, under which POC forecasting was car- ried out in two stages, was developed by us. In the first phase, before the operation, the scale included the following parameters: the nature of the underlying disease and peritonitis, parameters of the comorbidity class (Table 1). The results of variance analysis (Table 2) confirmed the statistically significant dependence of the POC from the indicators that were selected for prediction. It is significant, that the involvement of the indicators analysis which are widely used to predict (age, leukocyte count, urea, creatinine, etc.) $[1,4]$, no statistically significant dependence of POC parameters dispersion on the complex of the determined factors was found. This caused the usage opportunity of the factors, just listed in table 1 .

According to the amount of points, determined according to the scale, patients previously divided into several groups: normal (2-4 points), increased (5.7 points), medium (8-9 points) and high (more than 10 points) POC risk (Fig. 1). Such allocation of risk groups allows to use the necessary POC prevention measures at the stage of preoperative preparation.

The final risk determination is made, based on the data of intraoperative revision and laboratory tests. The clinical and laboratory parameters analysis sho-

Table 1

\section{A scale for postoperative septic complications of acute peritonitis predicting}

\begin{tabular}{|l|l|}
\hline Criteria & Points \\
\hline $\begin{array}{l}\text { Acute appendicitis, acute cholecystitis simple, gynecological pathology, intestinal } \\
\text { obstruction (non-tumor) without necrosis. }\end{array}$ & $\mathbf{1}$ \\
\hline $\begin{array}{l}\text { Intestinal obstruction (non-tumor) with necrosis, acute destructive cholecystitis, } \\
\text { perforation of gastroduodenal ulcers, small intestine, stomach cancer, acute peptic ulcer } \\
\text { bleeding, obstetrical pathology. }\end{array}$ & $\mathbf{2}$ \\
\hline $\begin{array}{l}\text { Abdominal trauma, tumor obstruction of the colon, Crohn's disease, acute pancreatitis, } \\
\text { mesenteric thrombosis, postoperative peritonitis. }\end{array}$ & $\mathbf{3}$ \\
\hline Local peritonitis & $\mathbf{2}$ \\
\hline Diffuse peritonitis & $\mathbf{4}$ \\
\hline Total peritonitis & $\mathbf{6}$ \\
\hline No class & $\mathbf{0}$ \\
\hline Comorbidity class 0 & $\mathbf{0}$ \\
\hline Comorbidity class 1 & $\mathbf{1}$ \\
\hline Comorbidity class 2 & $\mathbf{2}$ \\
\hline Comorbidity class 3 & $\mathbf{3}$ \\
\hline
\end{tabular}

Table 2

Results of the impact of certain factors on the development of postoperative complications in studied patients variance analysis

\begin{tabular}{|l|l|l|l|l|l|}
\hline Source & Sum of Squares & Df & Mean Square & F-Ratio & P-Value \\
\hline CC & 27,38 & 3 & 9,14 & 4,79 & 0,003 \\
\hline Peritonitis & 18,31 & 2 & 9,16 & 4,81 & 0,009 \\
\hline Main diagnosis & 69,73 & 18 & 3,87 & 2,03 & 0,011 \\
\hline Residual & 76,14 & 45 & 1,90 & - & - \\
\hline Total (corrected) & 497,76 & 168 & - & - & - \\
\hline
\end{tabular}




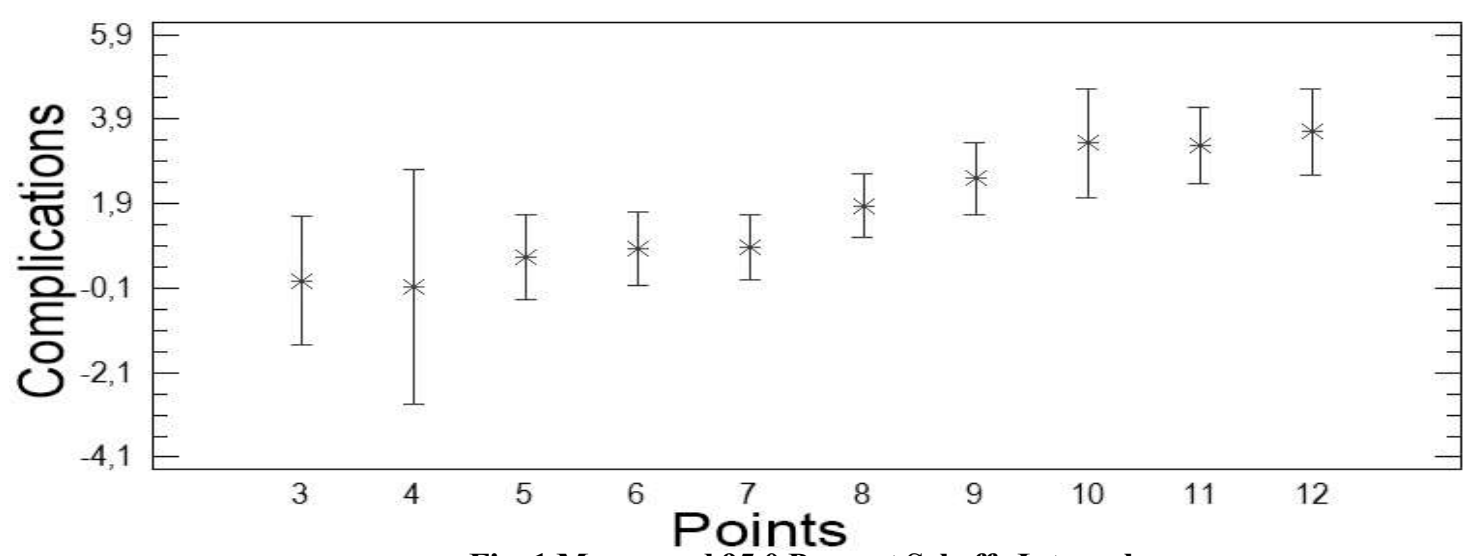

Fig. 1 Means and 95,0 Percent Scheffe Intervals

wed that POC parameters dispersion is statistically significantly explained by the insertion of the data, presented in table 3 . Based on the conducted analysis, a specified scale is created for the second phase prediction (tab. 4). The programmed peritoneal cavity sanation indicators were extra included, as the repeated surgery increases the POC risk [3].

Risk groups differentiation is conducted as follows: less than 18 points - normal, 18-25 points - increased (primarily wound complications), 26-34 points - average (abscesses, infiltrates, diffuse peritonitis, suture failure), more than 35 points - high risk ( severe peritonitis, sepsis), what was confirmed by the results of the univariate variance analysis (Fig. 2). The allocation of a particular patient to a specific group allows to use reasonably necessary preventive measures during surgery and in the postoperative period.

Table 3

Results of the impact of certain factors on the development of postoperative complications in studied patients variance analysis

\begin{tabular}{|l|l|l|l|l|l|}
\hline Source & Sum of Squares & Df & $\begin{array}{l}\text { Mean } \\
\text { Square }\end{array}$ & F-Ratio & P-Value \\
\hline CC & 27,06 & 3 & 9,09 & 8,00 & 0,0001 \\
\hline Peritonitis & 91,96 & 28 & 3,28 & 2,91 & 0,000 \\
\hline Stab neutrophils & 86,69 & 2 & 38,46 & 38,46 & 0,000 \\
\hline Main diagnosis & 4,24 & 2 & 1,88 & 1,88 & 0,156 \\
\hline Residual & 49,87 & 33 & 1,12 & - & - \\
\hline Total (corrected) & 497,76 & 168 & - & - & - \\
\hline
\end{tabular}

Table 4

A scale for preoperative complications predicting

\begin{tabular}{|l|l|}
\hline Criteria & Points \\
\hline Characteristics of surgical pathology & Due to table 1 \\
\hline Characteristics peritonitis & MPI \\
\hline Characteristics of the concominent disease & Due to table 1 \\
\hline Content of the stab neutrophils (\%) & \\
less than 3 or more than 37 & $\mathbf{3}$ \\
$26-36$ & $\mathbf{2}$ \\
$4-25$ & $\mathbf{0}$ \\
\hline The use of programmed sanation & $\mathbf{2}$ \\
\hline
\end{tabular}

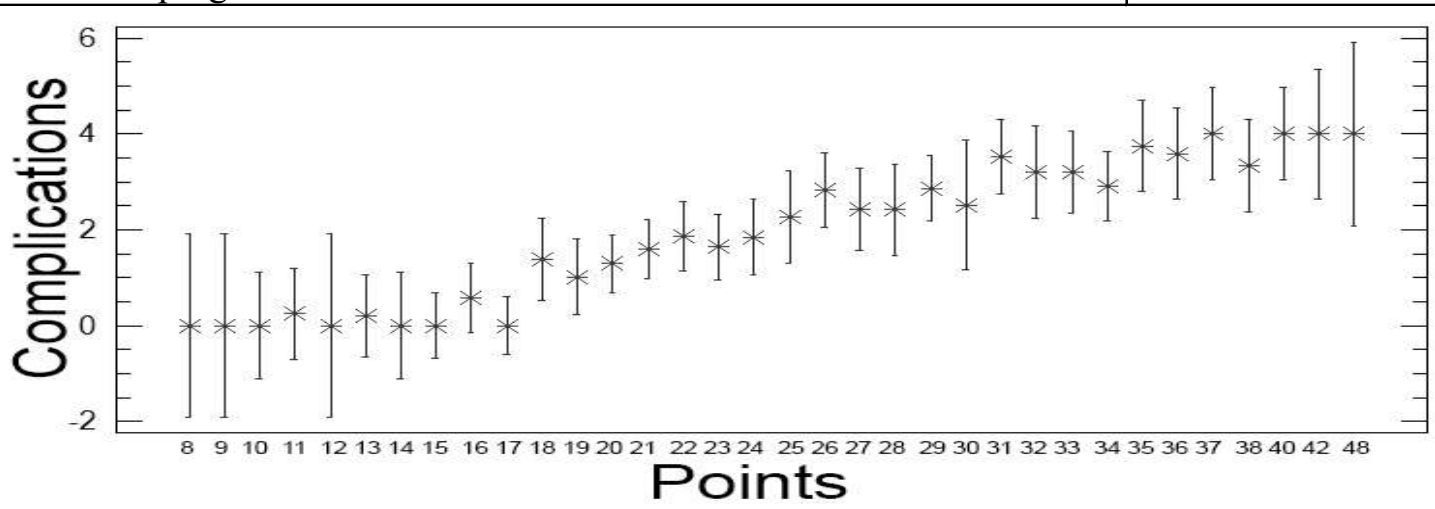

Fig. 2 Means and 95,0 Percent Scheffe Intervals 


\section{Conclusions}

1.The proposed prognostic scale allows to allocate reasonably groups of normal, increased, medium and high risk of postoperative complications at acute peritonitis.

2.Conducting the prediction in two phases - before and during surgery, can differentially apply preventive measures in the course of preoperative preparation, during the operation and in the postoperative period treatment.

\section{Prospects for further research}

Further research should be directed at reasonable postoperative complications preventing methods development.

Literature. 1.Камінський І.В. Прогнозування та профілактика післяопераційних гнійно-септичних ускладнень в абдомінальній хірургії / І.В. Камінський, О.В. Косенко, О.Ю. Гербалі // Шпитальна хірургія. 2013. - № 2. - С. 35-38 2.Матвійчук, Б. О. Лімфопенія як предиктор летальності пацієнтів із абдомінальним сепсисом / Б. О. Матвійчук, О. В. Лукавецький, В. Ю. Федоров // Шпит. хірургія. - 2015 . № 1. - С. 24-27. 3.Прогностична значущість показників ендогенної інтоксікації та системи монооксигенази на етапах хірургічного лікування хворих 3 приводу абдомінального сепсису / I.А. Криворучко, В.І. Жуков, М. С. Повеличенко С. А. Андреєщев // Клінічна хірургія. - 2014. - №3. - С. 5-9. 4.Чурпій I.К. Прогнозування перебігу хірургічного лікування розлитого перитоніту з урахуванням кількісної оцінки факторів ризику / I.К. Чурпій // Медична інформатика та інженерія.- 2011. - № 3. - С. 33-41. 5.Der Mannheimer Peritonitis - Index / M. M. Linder, H. Washa, U. Feldmann [et al.] // Chirurg.- 1987. - Vol. 58, № 2. - P. 84-92. 6.Grynchuk F. V. A new scoring system for comorbidity assessment in urgent abdominal surgery / F. V. Grynchuk, I. Yu. Polianskiy // Arta medica. - 2015. - № 3 (56). - P. 52-53. 7.New scoring system for predicting postsurgical complications in abdominal surgery / F.V. Grynchuk, I.Yu. Polianskiy, V.V Preutesei, A.F. Grynchuk // Arta medica. - 2015, - № 3 (56). - P. 53-54. 8.Predictors of relaparotomy after nontrauma emergency general surgery with initial fascial closure / J.J. Kim, M.K. Liang, A. Submarian [et al.] // Am. J. Surg.- 2012. - Vol. 202, № 5. - P. 549-552. 9.Risk factors for morbidity and mortality after single-layer continuous suture for ileocolonic anastomosis / A. Volk, S. Kersting, H.C. Held, H.D. Saeger// Int. J. Colorectal Dis.- 2012. - Vol. 90, № 1. - P. 11-16.

\section{ШКАЛА ДЛЯ ПРОГНОЗУВАННЯ ГНІЙНО- СЕПТИЧНИХ ПІСЛЯОПЕРАЦІЙНИХ УСКЛАДНЕНЬ ПРИ ГОСТРОМУ ПЕРИТОНІТІ}

\section{А.Ф. Гринчук, Ф.В. Гринчук, І.Ю. Полянський}

Резюме. Представлені результати ретроспективного аналізу результатів лікування 169 хворих на гостру хірургічну патологію органів черевної порожнини, ускладнену різними формами перитоніту, у 79 з яких розвинулись післяопераційні ускладнення. За допомогою дисперсійного аналізу вивчали залежність виникнення та тяжкості ускладнень від характеру основного захворювання, клінічних проявів перитоніту до операції, даних антропометричних досліджень, лабораторних методів, параметрів Мангаймського перитонітного індексу, класу коморбідності, віку. У результаті розроблена шкала, згідно з якою прогнозування ускладнень проводиться в два етапи. До операції оцінюється попередній ризик з урахуванням характеру основного захворювання, клінічних проявів перитоніту, класу поєднаної патології. Під час операції, беручи до уваги виявлені зміни, проводиться остаточна оцінка з урахуванням характеру основного захворювання, параметрів Мангаймського перитонітного індексу, класу коморбідності, кількості паличкоядерних нейтрофільних лейкоцитів, застосування запрограмованих повторних санацій очеревинної порожнини. Названим показникам надана визначена кількість пунктів. За їх сумою хворих відносять до груп звичайного (менше 18), збільшеного (18-25), середнього (26-34) і високого (більше $35)$ ризику розвитку ускладнень. Таке розмежування дає змогу застосовувати необхідні профілактичні заходи на всіх етапах лікування хворих, починаючи 3 передопераційної підготовки.

Ключові слова: гострий перитоніт, післяопераційні ускладнення, прогнозування.

\section{ШКАЛА ДЛЯ ПРОГНОЗИРОВАНИЯ ГНОЙНО- СЕПТИЧЕСКИХ ПОСЛЕОПЕРАЦИОННЫХ ОСЛОЖНЕНИЙ ПРИ ОСТРОМ ПЕРИТОНИТЕ}

\section{А.Ф. Гринчук, Ф.В. Гринчук, В.Ю. Полянский}

Резюме. Представлены результаты ретроспективного анализа результатов лечения 169 больных с острой хирургической патологией органов брюшной полости, осложненной различными формами перитонита, у 79 из которых развились послеоперационные осложнения. С помощью дисперсионного анализа изучали зависимость возникновения и тяжести осложнений от характера основного заболевания, клинических проявлений перитонита до операции, данных антропометрических исследований, лабораторных методов, параметров Мангаймского перитонитного индекса, класса сочетанной патологии, возраста. В результате разработана шкала, согласно которой прогнозирования осложнений осуществляется в два этапа. До операции оценивается предварительный риск с учетом характера основного заболевания, клинических проявлений перитонита, класса сочетанной патологии. Во время операции, с учетом выявленных изменений, проводится окончательная оценка с учетом характера основного заболевания, параметров Мангаймского перитонитного индекса, класса коморбидности, количества палочкоядерных нейтрофильных лейкоцитов, применения запрограммированных повторных санаций брюшинной полости. Названным показателям предоставлено определенное количество пунктов. По их сумме больных относят к группам обычного (менее 18), увеличенного (18-25), среднего (26-34) и высокого (более $35)$ риска развития осложнений. Такое разграничение позволяет применять необходимые профилактические мероприятия на всех этапах лечения больных, начиная с предоперационной подготовки.

Ключевые слова: острый перитонит, послеоперационные осложнения, прогнозирование.

ВГУЗ Украины "Буковинский государственный медицинский университет", г. Черновцы

Clin. and experim. pathol.- 2016.- Vol.15, №2 (56).p.1.-P.50-53.

Надійшла до редакиії 2.05.2016 Речензент - проф. В.П. Польовий (c) A.F. Grynchuk, F.V. Grynchuk, I.Iu. Polianskiy, 2016 